\title{
ECONOMIC ATTITUDES AND PERCEPTIONS OF POVERTY IN INDIGENOUS COLLEGE STUDENTS IN MEXICO FROM THE INTERCULTURAL APPROACH
}

\author{
Altayra Geraldine Ozuna Beltrán, Marco Alberto Nuñez Ramírez, \\ Imelda Lorena Vázquez Jiménez \\ Sonora Institute of Technology, Mexico \\ E-mail: altayra.geraldine@itson.edu.mx,marco.nunez@itson.edu.mx, \\ ivazquez@itson.edu.mx \\ Cecilia Lorena Velarde Flores \\ The College of Sonora, Mexico \\ E-mail: cvelarde@colson.edu.mx
}

\begin{abstract}
Behavioral economics has tried to explain the economic and financial decisions of the individuals. It has been used to understand the economic perceptions and attitudes of vulnerable groups; however, for indigenous peoples, especially in Latin America, there are unresolved issues. Thus, from an intercultural perspective, this research examines the association between the economic attitude and the perception of poverty through the comparison of a sample of intercultural college students from different ethnic groups in Mexico. For this reason, a quantitative, descriptive and correlational research was carried out with a non-experimental design from a sample of 207 intercultural college students. Two research questions were raised, the questions were tested by Pearson correlation and linear regression. Attribution theory was analyzed to assess the association between the economic attitude and the perception of poverty in intercultural students. It was found that the economic attitude is related to the perception of poverty, because the students presented attitudes of financial optimism oriented towards the structural causes of poverty. Consequently, the model of an intercultural university could benefit the development of indigenous communities, through a pedagogy oriented towards the creation of significant economic attitudes.

Keywords: behavioral economics, intercultural college students, financial optimism, perceptions of poverty.
\end{abstract}

\section{Introduction}

Attitudes and perceptions towards different economic and social phenomena depend largely on the education that individuals received; however, in the case of ethnic groups, there are other factors such as ancestral knowledge and worldviews that also influence the behavior of vulnerable groups. Among the social phenomena that affect the indigenous people is poverty. In order to understand the effect that this phenomenon has, it is imperative to study 
Altayra Geraldine OZUNA BELTRÁN, Marco Alberto NUÑEZ RAMÍREZ, Imelda Lorena VÁZQUEZ JIMÉNEZ, Cecilia Lorena VELARDE FLORES. Economic attitudes and perceptions of poverty in indigenous college students in Mexico from the intercultural approach

PROBLEMS

OF EDUCATION IN THE $21^{\text {st }}$ CENTURY Vol. 78 , No. 2, 2020

264

the attitudinal part related to the perception of poverty and economic attitudes, which can be explained through financial education.

Financial education is a high priority issue worldwide, especially in developing economies (Brimble \& Blue, 2015; Kaiser \& Menkhoff, 2019). This is due to financial education that can be seen as a tool to counteract poverty (Loomis, 2018), especially in vulnerable groups (Engelbrecht, 2008) such as indigenous people. The United States Agency for International Development ([USAID], 2019) consider that one of the processes that helps indigenous people to develop values, knowledge and behaviors for the financial decision-making is financial education; nevertheless, despite the above, this is an under-explored topic worldwide, especially in emerging economies with large indigenous populations.

Indigenous groups have faced a historical context of discrimination and inequality at the international level, which has led to adverse social and economic situations. In this regard, the Food and Agriculture Organization of the United Nations ([FAO], 2015) maintains that indigenous groups are among the most vulnerable and disadvantaged groups, accounting for approximately $15 \%$ of all people in extreme poverty worldwide. As far as education is concerned, the United Nations Educational, Scientific and Cultural Organization ([UNESCO], 2015) states that a small percentage of ethnic groups have access to higher education: $4 \%$ in South Africa, 12\% in Central Asia, 13\% in North Africa, 13\% in Western Asia and 21\% in Latin America.

It is important to note that Latin America is one of the regions with the largest number of indigenous inhabitants in the world, with Mexico having the largest population (Economic Commission for Latin America and the Caribbean [CEPAL], 2014). According to the National Institute of Statistics and Geography ([INEGI], 2015), Mexico ranks eighth worldwide in countries with the largest indigenous population and the second in the Americas; there are 68 indigenous people with 364 variations (National Institute for Indigenous People [INPI], 2009). It is important to note that these ethnic groups are characterized as the most marginalized groups in Mexico because there are more than 7.4 million people who belong to an original town where $71.9 \%$ of them live in poverty; in addition, $90.8 \%$ of indigenous language speakers are in this situation (INPI, 2018). Poverty has had consequences in areas such as education, health and income. According to the National Council for the Evaluation of Social Policy (CONEVAL, 2018), 3.2 million indigenous people cannot acquire the basic basket, 77.6\% do not have medical services and $52.9 \%$ are illiterate.

According to Solis (2017), regarding to university education, the lack of access to higher education is a relevant problem, particularly for indigenous youth in Mexico. In fact, UNESCO (2015) mentions that less than $2 \%$ of the indigenous population joins higher education; in addition, the percentage that manages to graduate is $1 \%$. One of the reasons why they do not finish their studies is that they are in a situation of poverty or extreme poverty, which limits their opportunities for development.

According to Schmelkes (2013), any effort to analyze indigenous groups represents a contribution to social equity; furthermore, considering that the concepts of poverty and indigenous people have gone hand in hand in Mexico and throughout Latin America, it is necessary to seek alternatives to address these vulnerable groups. One of these could be financial education, which is a topic that has not been intensively studied worldwide. Among the empirical evidence, it is possible to highlight the conducted studies in Australia (e.g., Bajada \& Trayler, 2014; Blue \& Grootenboer \& Brimble, 2015; Wagland \& Taylor, 2015); while in Mexico the literature is scarce (e.g., Schmelkes, 2011).

Considering these elements, the study of this context in Mexico could generate relevant information to understand how financial education could have a positive impact on indigenous people in other countries. It should be noted that one of the strategies to include the indigenous population in higher education was the emergence of intercultural universities, which according 
Altayra Geraldine OZUNA BELTRÁN, Marco Alberto NUÑEZ RAMÍREZ, Imelda Lorena VÁZQUEZ JIMÉNEZ, Cecilia Lorena VELARDE FLORES. Economic attitudes and perceptions of poverty in indigenous college students in Mexico from the intercultural approach

to Márquez (2016), seek to offer a differentiated education appropriate to the cultural reality of the country. According to the Ministry of Public Education (2018), there are 11 intercultural universities in Mexico, located in different states such as Tabasco, Michoacán, Chiapas, State of Mexico, Sinaloa, Hidalgo, Guerrero, Puebla, Quintana Roo, San Luis Potosi and Veracruz. That is why the university could be an agent of change in vulnerable regions where intercultural and indigenous groups live in developing countries, as is the case in Mexico (Avila, 2011; Erdosova, 2013; Marquez, 2016); however, considering that this is a subject that has not been studied in depth, what theoretical position would be convenient to understand financial education in the indigenous context? Therefore, this research was based on two theoretical positions: 1) interculturality, and 2) behavioral economics.

First of all, interculturality is based on the understanding of the relation between groups or societies, including their different practices and thoughts (Walsh, 2005). According to Dietz \& Mateos (2010), in the case of Latin America, interculturality has been associated with educational policies aimed at promoting the development of indigenous peoples, as well as the preservation of their language. Briones et al. (2006) affirmed that interculturality can be used for distinctive elements of indigenous culture in order to understand national identity. It is important to note that Mexico has been considered a multicultural country, since different ethnic groups live together, which are distinguished by having a particular worldview; however, these differ in their languages, customs and traditions (Schmelkes, 2004). Consequently, from the intercultural educational approach, the existence of spaces that allow the promotion of these elements is important. In this context it is where the intercultural university model emerges, which seeks to provide higher education to indigenous students in order to become development agents that have a positive impact on their communities (Ávila, 2011).

On the other hand, there is the behavioral economy, which serves to explain human behavior, through the use of knowledge provided by basic economics, statistics and finance, elements with an important role in economic decisions (Barraje, 2019; Katona, 1975). Since its emergence during the 1960s and 1970s, this discipline has been of great interest to the academic community (Fonseca et al., 2019; Paule-Vianez et al., 2020), where perceptions and attitudes have played an important role in understanding economic decisions and social problems. The growth of this problem and its consequences has caused an increase in the perceptions of the population, highlighting to the causes of poverty (Giarrizo, 2006). According to the theory of attribution, the process of explaining and interpreting events makes it possible to evaluate the origin of behavior, which influences the way of perceiving social phenomena (Heider, 1958). It should be noted that within these phenomena of study is the perception of poverty (Dakduk et al., 2010).

Mazabel and Diaz (2011) mentioned that it is important to know the person's perceptions related to the causes of poverty in order to generate proposals. The problem of poverty is so complex that each country has a different reality. There are conducted studies in different countries that argue that one of the factors explaining poverty is the perception (e.g. government, destination, culture).

The perception of poverty has been addressed by various disciplines, such as psychology, economics, anthropology and sociology. According to Carr and Sloan (2003), one of the approaches to the research of poverty is the one that takes into account the reactions, appreciations and behaviors of social groups. From this perspective, in 1970 a theoretical proposal by Feagin (1972) was originated. He provided the basis for the development of this research line. It sought to identify the judgments that people established as possible causes that caused poverty and the characteristics of the people who suffered it (Dakduk et al., 2010).

According to Stiglitz (2002), the origins of the perception of poverty have economic bases; and the consequences that can cause it are not only economic and social, but also psychological, which explains why perception needs to be studied from sciences such as
PROBLEMS

OF EDUCATION

IN THE $21^{\text {st }}$ CENTURY

Vol. 78, No. 2, 2020 
Altayra Geraldine OZUNA BELTRÁN, Marco Alberto NUÑEZ RAMÍREZ, Imelda Lorena VÁZQUEZ JIMÉNEZ, Cecilia Lorena VELARDE FLORES. Economic attitudes and perceptions of poverty in indigenous college students in Mexico from the intercultural approach

PROBLEMS

OF EDUCATION IN THE $21^{\text {st }}$ CENTURY Vol. 78, No. 2, 2020

266

behavioral economics. Within the studied aspects by the behavioral economy, is the human behavior (Quintanilla, 2000). It is formed by the judgments, exchange of ideas, perceptions and attitudes to a situation or phenomenon in particular. Regarding the attitudes, Merolla et al. (2011) maintained that they help to predict the behavior of individuals and have relevance in the life of individuals who are in conditions of vulnerability.

Within the attitudes of individuals is the economic attitude, which was defined by Denegri et al. (2011) as the subjective position that individuals adopt related to economic decision-making in order to satisfy their material needs. Therefore, knowing certain economic attitudes and associating them with the perception of poverty can contribute to understand this phenomenon and, later, generate strategies to mitigate this problem that especially afflicts the ethnic groups.

\section{Literature Review}

\section{Background of the Behavioral Economics}

Behavioral economics has been studied by different disciplines such as psychology, sociology, anthropology, biology and economics (Quintanilla, 2000). Esguerra (2016) established that behavioral sciences refer to the research of people and decision making that for years has been studied to create more accurate models. According to this author, the behavioral approach teaches us that individuals make decisions contemplating different factors and that the best choice is not always chosen. The human behavior approach has allowed the economy to be enriched with several elements to strengthen its analysis. In this sense, Kahneman (2003) has followed a line of research that tries to explain the decisions of the economic agents, which was called behavioral economics.

Behavioral economics has been defined as the study of human daily life through practices, exchanges, judgments and perceptions, and how these influence the reasoning when making economic decisions (Quintanilla, 2000). In addition, this discipline is the combination of psychology and economics to investigate how markets react to the complications and limitations of human beings (Mullainathan \& Thaler, 2000).

The theory of the perspectives of Kahneman and Tversky (1979) has been presented as a series of assumptions that challenge the expected utility theory. They point out that people think in terms of profits, losses and results, trying to explain why people prefer safe results instead of a situation with higher expectations. This theory is based on three main ideas: the first one is about the representativeness, availability, anchorage and the biases that individuals use in decision-making moments; the second one refers to low-risk decision models; and the last one has to do with the framing and its consequences in rational models (Kahneman, 2003).

In the ambit of the studied aspects of behavioral economics, the most important is the human behavior (Mullainathan \& Thaler, 2000); on the other hand, within the individuals' behavior are the judgments, exchange of ideas, perceptions and attitudes that are presented in a particular situation or phenomenon; and finally, the studied social attitudes include the economic attitude and the perception of poverty, variables that are explained below.

\section{Economic Attitudes}

Different definitions of economic attitude have emerged. Firstly, according to Denegri et al. (2011), it has been considered as the subjective position that individuals adopt with respect to economic decision-making in order to satisfy their material needs. Meanwhile for Yamani (1997), it is a construct that refers to that set of beliefs, abilities and skills that allow individuals to understand the near and global economic environment to make efficient decisions 
Altayra Geraldine OZUNA BELTRÁN, Marco Alberto NUÑEZ RAMÍREZ, Imelda Lorena VÁZQUEZ JIMÉNEZ, Cecilia Lorena VELARDE FLORES. Economic attitudes and perceptions of poverty in indigenous college students in Mexico from the intercultural approach

according to their financial resources. On the other hand, economic attitude refers to the way of economically acting in different situations, to the efficient use of money and to the correct use of the resources that people have (Zabelina et al., 2018).

Regarding the factors that influence the economic attitude, Alagoz (2015) divided the variable into two categories: attitude towards economic sciences and sophisticated economic attitudes. The first category groups together aspects related to enjoying economic information and economic analysis. The second one refers to the attitudes of individuals towards issues such as the charging of bank interest, as well as the government intervention in gasoline prices, the causes of inflation, business profits and strikes; unlike Kasser and Ahuvia (2002), which measures economic attitudes based on nine categories: frugality that measures prudence towards the use of economic resources, generosity, materialism, happiness, anxiety, self-esteem, risk behavior, conservation of environmental resources and imaginary profits.

There are other scales to measure the economic attitude of people; for example, Zabelina et al. (2018) proposed the following factors: (1) economic internality and financial optimism, which alludes to future financial thoughts, such as the idea of owning material goods, the increase in income, and the tendency to save. (2) economy estimate factor that measures attitudes towards investment, consumption, inflation knowledge, frequency of donations, financial competition and knowledge of the financial economic environment. Finally, (3) the financial literacy and satisfaction factor which measures questions about the security of the financial future, consumption, as well as the analysis of bank investments.

\section{Perception of Poverty}

Behavioral economics studies people's attitudes and perceptions. According to Heider (1958), perceptions allow us to evaluate behavior, which is related to the way we perceive social phenomena. In addition, the perception of individuals has been considered one of the cornerstones in the study of social aspects (Moscovici, 1984).

Within these social phenomena, is the perception of poverty, which according to Carr and Sloan (2003) took into account the appreciations and behaviors of a social group towards a particular phenomenon; likewise, Feagin (1972) defined it as the predominant judgments that people establish as causes of poverty and their defining characteristics. In addition to the above, Narayan (2000) affirmed that the perception of poverty includes aspects such as corporal, social, psychological well-being, security and the freedom of choice and action.

Hagenaars and de Vos (1988) mentioned that the perception of poverty is related to the feeling that you do not have enough to live on. For Vázquez et al. (2007), this variable is the one that recognizes that the appraisals of different societies involve a load of judgements created in the environment, which are intimately linked to a precise historical moment and to a particular culture. Pinazo (2010) established that the perception of poverty are the judgments, beliefs, expectations and motivations about the phenomenon of poverty.

Different taxonomies have emerged on the perception of poverty. Firstly, it was Feagin (1972) who grouped beliefs related to the causes of poverty into three categories: (1) individual causes that attribute it to the lack of skills, effort or lack of savings; (2) the social causes that attribute the perception of poverty to the exploitation of the poor, lack of education and low wages; (3) the cause of fatalism that attributes the perception to fatalism that contemplates bad luck, or issues that have no control. It should be noted that the first category states that the poor are responsible for their condition and the other two are due to external causes.

On the other hand, Golding and Middleton (1982) use four factors as causes of poverty: prodigality, injustice, deprivation and fatalism. This coincides with the position of Shek (2002), who found four factors to which he names: personal factors, lack of opportunities, exploitation and fate; moreover, Lewis and Furnham (1986) found the following factors: external-social, internal, family background and luck-risk variables.
PROBLEMS

OF EDUCATION

IN THE $21^{\text {st }}$ CENTURY

Vol. 78 , No. 2, 2020 
Altayra Geraldine OZUNA BELTRÁN, Marco Alberto NUÑEZ RAMÍREZ, Imelda Lorena VÁZQUEZ JIMÉNEZ, Cecilia Lorena VELARDE FLORES. Economic attitudes and perceptions of poverty in indigenous college students in Mexico from the intercultural approach

PROBLEMS

OF EDUCATION IN THE $21^{\text {st }}$ CENTURY Vol. 78, No. 2, 2020

Harper's model (1990) attributes poverty to four factors that are grouped into the following categories: the first one is called deterministic, which it attributes poverty to dispositional and characteristic causes of the inhabitants of the third world; the second factor refers to governments, which refers to government management, corruption and pervasive incompetence.

The third nature factor attributed poverty to the natural conditions of the environment in which they lived; the fourth and final factor, exploitation, was about the pressure the first world exerts to perpetuate poverty in the third world. Hine and Montiel (1999) incorporated the fifth factor called conflict that attributes the causes of poverty to wars and political conflicts that impede economic development.

Pinazo's model (2010) was chosen for the present research and groups three categories: theory of cultural learning, theory of factual powers and deterministic theory. The first one gathers the image of a social group that learns cultural norms and keys, and people that individually interiorize the cultural keys translating into a way of seeing and responding in the world; the responsibility is attributed to the personal characteristics of the population of the poor countries, who do nothing to get out of their poverty.

The second one reflects the image of help that poverty is caused by the pressure and exploitation of the economic and political powers of developed countries; and the deterministic theory states that people believe that poverty exists because there are certain forces of fate or a lazy and opportunistic nature in the world that lead some people to be poor; according to this dimension, responsibility falls on nature, poverty is something natural has always existed and will exist.

\section{Research Problem}

The research of the economic attitude and the perception of poverty has allowed that there is enough empirical evidence at international level (Zabelina et al., 2018). Regarding the association between both variables, the main approximations that exist are from Feagin (1972), who associates psychological factors such as attitudes towards saving and administration of resources with a perception of poverty; and Hunt (2004) when associating perception of poverty with attitudes towards wealth.

In the case of Mexico, studies related to economic attitude have focused on the measurement of entrepreneurial attitude and intention (Palomar \& Cienfuegos, 2006); however, with regard to the perception of poverty, Reyes et al. (2014) found that the Raramuris feel poor because they do not have the availability of food, drainage services, electricity and drinking water. They also mention structural issues such as the poor implementation of public policies as the main cause of poverty.

Torres et al. (2007) found that $68.4 \%$ of the Nahuatl indigenous people mention factors such as food, lack of basic services, lack of health services and illiteracy as the main causes of poverty, while $29.8 \%$ mentioned low income as the main cause. Cimadamore et al. (2006) found that, despite these problems, indigenous peoples move forward because within their intercultural context, they develop skills such as specific beliefs, values, behaviors and attitudes.

However, despite the efforts that have been made to research both variables, there is a need for more empirical evidence that relates the economic attitude and the perception of poverty in intercultural environments; therefore, the understanding of these variables has not been entirely clear. For this reason, it is imperative that the attitudinal part of indigenous peoples be researched. 
Altayra Geraldine OZUNA BELTRÁN, Marco Alberto NUÑEZ RAMÍREZ, Imelda Lorena VÁZQUEZ JIMÉNEZ, Cecilia Lorena VELARDE FLORES. Economic attitudes and perceptions of poverty in indigenous college students in Mexico from the intercultural approach

From the foregoing, the following hypotheses were arisen (See Figure 1):

$H_{l}$ : The economic attitude and perception of poverty in intercultural students in Mexico correlate significantly and positively.

$H_{2}$ : Economic attitude positively and significantly influences the perception of poverty among intercultural students in Mexico.

\section{Figure 1}

Hypothetical model

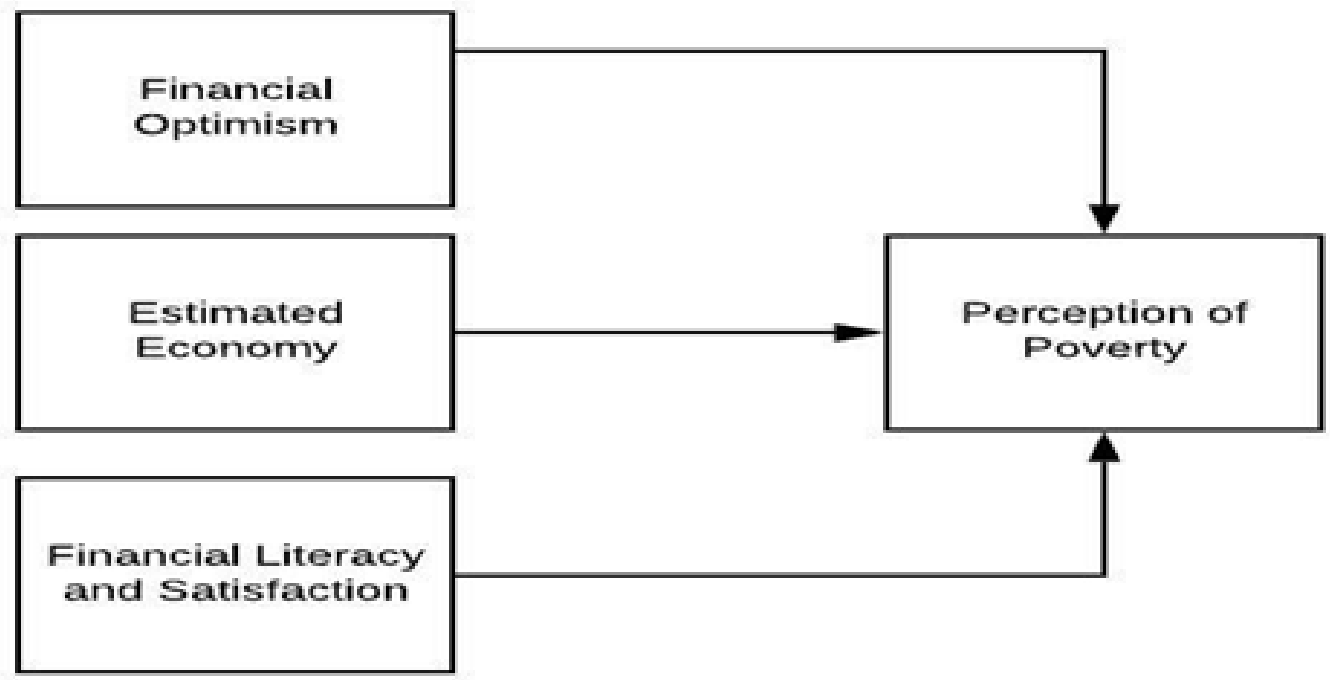

The relevance of this research lies in the fact that there are no studies that associate the perception of poverty and economic attitude in intercultural students; hence, the proposed research could help to understand both variables that are important in the lives of intercultural students.

According to Lewis et al. (1995), in addition to the entrepreneurial attitudes, other economic attitudes must also be studied in order to have a systematic view of the minds of young people. The results of the research could help participating schools to create curricula that identify attitudes towards investment and savings in order to correct financial behavior, which will help to understand perceptions of poverty.

\section{Research Methodology}

\section{General Background}

In order to test the research hypotheses, a quantitative and correlational research was carried out; in addition, it was transversal because the information is collected once in time, and its design was non-experimental since no type of manipulation was used on the variables, nor in the selection of the subjects. Firstly, the research was quantitative due to the use of numerical data, which were obtained through the application of a survey (Hernández et al., 2014). It was correlational because it measures the level of relation between different variables (Ho, 2006), which were the economic attitudes and perceptions of poverty of intercultural students in Mexico; while its design was non-experimental, since no control or manipulation was exercised on the independent variables (Kerlinger \& Lee, 2002). The research population is described below. 
Altayra Geraldine OZUNA BELTRÁN, Marco Alberto NUÑEZ RAMÍREZ, Imelda Lorena VÁZQUEZ JIMÉNEZ, Cecilia Lorena VELARDE FLORES. Economic attitudes and perceptions of poverty in indigenous college students in Mexico from the intercultural approach

PROBLEMS

OF EDUCATION

IN THE $21^{\text {st }}$ CENTURY

Vol. 78 , No. 2, 2020

270

Sample

The measurement questionnaire and a letter of introduction were sent to the authorities of different colleges from the northwest region of Mexico, where students from ethnic groups are taking courses. The questionnaire was self-administered in the institutions that approved to participate in this research. Initially, it was desired to carry out a probability sampling of clusters considering the size of each educational institution; however, this was not possible due to the following aspects: 1) it was not possible to know the student data; 2) it was not feasible to access all groups due to different school activities. Therefore, a sample consisting of 207 students from the Mexican states of Sonora and Sinaloa was obtained, through a convenience sampling. Even though, it is important to note that, although this type of non-probabilistic sampling is not entirely recommended, it can be used for scientific purposes, as long as the analysis of the obtained data is properly done (Kerlinger \& Lee, 2002).

Table 1

Characteristics of the sample

\begin{tabular}{|c|c|c|}
\hline Characteristics & $n$ & $\%$ \\
\hline \multicolumn{3}{|l|}{ Age } \\
\hline $15-18$ & 92 & 45 \\
\hline $19-23$ & 106 & 51 \\
\hline $24-30$ & 9 & 4 \\
\hline \multicolumn{3}{|l|}{ Gender } \\
\hline Female & 102 & 49 \\
\hline Male & 105 & 51 \\
\hline \multicolumn{3}{|l|}{ Educational programs } \\
\hline Management of intercultural business & 25 & 12 \\
\hline Industrial Engineering & 47 & 23 \\
\hline Quality Systems Engineering & 22 & 11 \\
\hline Social Psychology & 2 & 1 \\
\hline Computer systems & 6 & 3 \\
\hline Bachelor of Law & 2 & 1 \\
\hline Bachelor in Alternative Tourism & 6 & 3 \\
\hline Accounting & 12 & 6 \\
\hline Forestry engineering & 5 & 2 \\
\hline Management and rural entrepreneurship & 58 & 28 \\
\hline Agricultural & 22 & 11 \\
\hline \multicolumn{3}{|l|}{ Ethnic Group } \\
\hline Yaqui & 155 & 75 \\
\hline Mayo & 9 & 4 \\
\hline Mixteco & 20 & 10 \\
\hline Others * & 23 & 11 \\
\hline
\end{tabular}

*Others: Tepehuano, Chatino, Tarahumana, Tzotzil, Zapoteco, Náhuatl and Chinanteco. 
Altayra Geraldine OZUNA BELTRÁN, Marco Alberto NUÑEZ RAMÍREZ, Imelda Lorena VÁZQUEZ JIMÉNEZ, Cecilia Lorena VELARDE FLORES. Economic attitudes and perceptions of poverty in indigenous college students in Mexico from the intercultural approach

\section{Research Process}

As ethical procedures, after planning the research, authorization was requested from the authorities of the participating educational institutions in Sinaloa and Sonora, Mexico. In addition, it should be noted that this authorization was obtained at each of the educational institutions, and that the students participated voluntarily after being informed the purpose of the research, as well as the confidentiality of the results. In order to collect the information, consent was first requested to the educational authorities to apply the questionnaire to the students, who were invited to participate on a voluntary basis and ensuring the reliability of their responses.

\section{Instrument Procedures}

For the measurement of the two variables, two questionnaires were used. Firstly, for the economic attitude variable, the "diagnosis of economic attitudes" questionnaire proposed by Zabelina et al. (2018) was applied. It should be noted that a Spanish version of the questionnaire was used. The instrument measures the economic attitude through three dimensions: economy and financial optimism, attitudes in the estimated economy and attitudes of satisfaction and literacy in finance. The instrument has a total of 16 questions, which were measured through 7 point Likert scale, where the options were: $1=$ totally disagree, $2=$ slightly disagree, $3=$ slightly disagree, $4=$ neither agree, nor disagree, $5=$ slightly agree, $6=$ agree and $7=$ totally agree.

For the poverty perception variable, "The causes of poverty in the third world questionnaire" proposed by Pinazo (2010) in Spanish version was used, which has three dimensions: theory of cultural learning, theory of factual powers and deterministic theory. It is made up of 20 items with a 7- point Likert scale. The questionnaire was first reviewed by academics who expressed their opinion about the items and dimensions. Alternatively, the reliability of the questionnaires was carried out using the Cronbach's Alpha coefficient with the following levels: economy and financial optimism $(\alpha=.688)$, attitudes in the estimated economy $(\alpha=.648)$, attitudes of satisfaction and literacy in finance $(\alpha=.646)$, theory of cultural learning $(\alpha=.737)$, theory of factual powers $(\alpha=716)$ and deterministic theory $(\alpha=.722)$.

\section{Data Analysis}

For the analysis of descriptive and inferential statistics, it was necessary to create a database. Subsequently, descriptive statistics were calculated to characterize the sample; furthermore, the Cronbach alpha reliability test was used for the dimensions of both variables. Pearson correlation test was used to find whether the variables were associated. As for the second hypothesis, linear regression test was applied to find whether economic attitude influences the perception of poverty, through the application of three models. The data were analyzed using SPSS (version 24).

\section{Research Results}

As a first step, Table 2 presents the descriptive results by variables and their respective dimensions through the use of Mean $(M)$ and Standard Deviation $(S D)$. In general terms, the dimensions of poverty perception $(M=4.70 ; S D=1.14)$ obtained higher results than economic attitudes $(M=4.13 ; S D=1.22)$, considering that both variables were measured using the same scale.
PROBLEMS

OF EDUCATION

IN THE $21^{\text {st }}$ CENTURY

Vol. 78, No. 2, 2020

271 
Altayra Geraldine OZUNA BELTRÁN, Marco Alberto NUÑEZ RAMÍREZ, Imelda Lorena VÁZQUEZ JIMÉNEZ, Cecilia Lorena VELARDE FLORES. Economic attitudes and perceptions of poverty in indigenous college students in Mexico from the intercultural approach

PROBLEMS

OF EDUCATION IN THE $21^{\text {st }}$ CENTURY Vol. 78 , No. 2, 2020

Table 2

Descriptive results

\begin{tabular}{lll}
\hline Variables & $\boldsymbol{M}$ & $\boldsymbol{S D}$ \\
\hline 1.Financial optimism & 4.77 & 1.13 \\
2.Estimated economy & 4.63 & 1.02 \\
3.Financial literacy and satisfaction & 4.71 & 1.27 \\
\hline Economic Attitudes & 4.70 & 1.14 \\
\hline 4. Theory of cultural learning & 4.28 & 1.14 \\
5. Theory of factual powers & 4.59 & 1.17 \\
6. Deterministic theory & 3.52 & 1.36 \\
\hline Perception of poverty & 4.13 & 1.22 \\
\hline
\end{tabular}

$M=$ Mean; $S D=$ Standard Deviation.

The first hypothesis raised was the economic attitude and the perception of poverty among intercultural students in Mexico, and they correlate significantly and positively. Empirical evidence was found that both variables were significantly correlated $(r=404 ; p$ $>01$ ). Something similar was observed when associating the dimensions of the variables, which were also related in a significant and positive way; the interaction between the following dimensions stands out: financial optimism - theory of factual powers $(r=.474 ; p<0.01)$, estimated economy - theory of factual powers $(r=.426 ; p<.01)$, satisfaction and literacy in finance - theory of factual powers $(r=.387 ; p<.01)$; however, this did not happen in the dimension 3 of poverty deterministic theory with estimated economy $(r=.123)$ and satisfaction and literacy in finance $(r=.052)$, which did not obtain significant results (See Table 3).

Table 3

Correlation of variables

\begin{tabular}{lllllll}
\hline Variables & $\mathbf{1}$ & $\mathbf{2}$ & $\mathbf{3}$ & $\mathbf{4}$ & $\mathbf{5}$ & $\mathbf{6}$ \\
\hline 1.Financial optimism & 1 & & & & \\
\hline 2.Estimated economy & $.581^{* *}$ & 1 & & & \\
\hline 3.Financial literacy and satisfaction & $.551^{* *}$ & $.628^{* *}$ & 1 & & \\
\hline 4. Theory of cultural learning & $.396^{* *}$ & $.314^{* *}$ & $.327^{* *}$ & 1 & \\
\hline 5. Theory of factual powers & $.474^{* *}$ & $.426^{* *}$ & $.387^{* *}$ & $.655^{* *}$ & 1 \\
\hline 6. Deterministic theory & $.139^{*}$ & .123 & .052 & $.526^{* *}$ & $.352^{* *}$ & 1 \\
\hline$* * p>.01$ (2-tailed). $* p>.05$ (2-tailed). & & & &
\end{tabular}

The second hypothesis was that the economic attitude positively and significantly influences the perception of poverty among intercultural students in Mexico. Using linear regression, the influence of economic attitude through its dimensions on the perception of poverty was researched. In addition, it is important to note that, when performing this test, no collinearity problems were found among the independent variables, because according to Field (2009), correlation values are considered acceptable when they are lower than .80 (See Table 3 ), while VIF values were acceptable in all cases; it is because low values show absence of collinearity problems (Hair et al. 2014), 
Altayra Geraldine OZUNA BELTRÁN, Marco Alberto NUÑEZ RAMÍREZ, Imelda Lorena VÁZQUEZ JIMÉNEZ, Cecilia Lorena VELARDE FLORES. Economic attitudes and perceptions of poverty in indigenous college students in Mexico from the intercultural approach

Tables 4 to 6 present the results of the regressions. Regarding their interpretation, four models are proposed, which correspond to the four independent variables: 1) control variables (ethnic group and gender), 2) Financial Optimism, 3) Estimated economy and 4) Deterministic theory. In essence, these results can be summarized as follows: 1) belonging to an ethnic group significantly affected economic attitudes; 2) the three dimensions of poverty perception also were positively affected by the independent variable; however, the lowest levels were found in the Deterministic theory. The theory of cultural learning, considering as variable dependent, was influenced by two dimensions of Economic Attitudes. After the regressions, model 3 was the most acceptable $\left(F=18.433 ; p<.001 ; \mathrm{R}^{2}=27 \%\right)$ (See Table 4$)$.

\section{Table 4}

Linear Regression: Theory of cultural learning as variable dependent

\begin{tabular}{|c|c|c|c|c|}
\hline Variables & Model 1 & Model 2 & Model 3 & Model 4 \\
\hline \multicolumn{5}{|l|}{ Control Variables } \\
\hline \multirow[t]{2}{*}{ Ethnic Group } & $.229^{* *}$ & $.203^{\star *}$ & $.173^{\star \star}$ & $.167^{\star *}$ \\
\hline & $(-.035)$ & $(-.032)$ & $(-.031)$ & $(-.031)$ \\
\hline \multirow[t]{2}{*}{ Gender } & 0.026 & -0.067 & -.049 & -.04 \\
\hline & $(-.154)$ & $(-.143)$ & $(-.137)$ & $(-.139)$ \\
\hline \multirow{2}{*}{ Financial optimism } & & $.389^{* \star *}$ & $.164^{*}$ & $.202^{*}$ \\
\hline & & $(-.062)$ & -0.079 & -.087 \\
\hline \multirow{2}{*}{ Estimated economy } & & & $.345^{\star * *}$ & $.348^{\star \star *}$ \\
\hline & & & $(-.078)$ & $(-.078)$ \\
\hline \multirow{2}{*}{ Deterministic theory } & & & & -.07 \\
\hline & & & & $(-0.06)$ \\
\hline $\mathrm{R}^{2}$ & .053 & .202 & .269 & .273 \\
\hline Adjusted $\mathrm{R}^{2}$ & .044 & .190 & .254 & .255 \\
\hline $\mathrm{F}$ & $5.707^{* *}$ & $37.917^{\star * \star}$ & $18.433^{* * *}$ & 1.184 \\
\hline VIF & 1.001 & 1.016 & 1.78 & 1.41 \\
\hline
\end{tabular}

It is important to highlight that belonging to an ethnic group significantly affected on all dimensions of poverty perception; even this happened when this element was used as a control variable. However, in all these cases, the explanation level $\left(\mathrm{R}^{2}\right)$ was low. Whereas, in the case of gender, it had no effect on the dependent variables. In Table 5 it can be seen that only the theory of factual powers as dependent variable was impacted by Financial optimism $(\beta=.308$; $p<.001)$ and Financial optimism $(\beta=.354 ; p<.001)$. 
Altayra Geraldine OZUNA BELTRÁN, Marco Alberto NUÑEZ RAMÍREZ, Imelda Lorena VÁZQUEZ JIMÉNEZ, Cecilia Lorena VELARDE FLORES. Economic attitudes and perceptions of poverty in indigenous college students in Mexico from the intercultural approach

PROBLEMS

OF EDUCATION

IN THE $21^{\text {st }}$ CENTURY

Vol. 78 , No. 2, 2020

Table 5

Linear Regression: Theory of factual powers as dependent variable

\begin{tabular}{|c|c|c|c|c|}
\hline Variables & Model1 & Model 2 & Model 3 & Model 4 \\
\hline \multicolumn{5}{|l|}{ Control Variables } \\
\hline \multirow[t]{2}{*}{ Ethnic Group } & $.223^{* * *}$ & $.293^{* *}$ & $.171^{* *}$ & $.168^{* *}$ \\
\hline & $(-.031)$ & $(-.03)$ & $(-.029)$ & $(-.029)$ \\
\hline \multirow[t]{2}{*}{ Gender } & -.041 & -.703 & -0.055 & -.05 \\
\hline & $(-.14)$ & $(-.134)$ & $(-.129)$ & $(-.130)$ \\
\hline \multirow{2}{*}{ Financial optimism } & & $.308^{\star * *}$ & $.076^{* * *}$ & -.094 \\
\hline & & -0.058 & $(.074)$ & $(-.081)$ \\
\hline \multirow{2}{*}{ Estimated economy } & & & $.354^{\star * *}$ & $.356^{\star * *}$ \\
\hline & & & $(-.073)$ & $(-.073)$ \\
\hline \multirow{2}{*}{ Deterministic theory } & & & & -37 \\
\hline & & & & $(-.056)$ \\
\hline $\mathrm{R}^{2}$ & .051 & 0.144 & 0.214 & .215 \\
\hline Adjusted $\mathrm{R}^{2}$ & .042 & .131 & 0.199 & .196 \\
\hline $\mathrm{F}$ & $5.472^{\star *}$ & $22.079^{\star \star *}$ & $18.119^{\star \star \star}$ & .254 \\
\hline VIF & 1.001 & 1.016 & 1.783 & 1.418 \\
\hline
\end{tabular}

$* * * p<.001 ; * * p<.01 ; * p<.05 ;$ (standard error); VIF = Variance Inflation Factor

On the other hand, although $\mathrm{R}^{2}$ were lower than $30 \%$, it is worth noting the significance levels obtained, which in most cases were statistically significant $(p<.001)$. Unlike Tables 4 and 5 , in Table 6 , the Deterministic theory had a significant impact on the dependent variable, although it was negative: Financial Literacy and Satisfaction $(\beta=-.159 ; p<.05)$. According to this evidence, it can be seen that the second hypothesis was only empirically supported when considering two dimensions of the poverty perception: the theory of cultural learning and the theory of factual powers. 
Altayra Geraldine OZUNA BELTRÁN, Marco Alberto NUÑEZ RAMÍREZ, Imelda Lorena VÁZQUEZ JIMÉNEZ, Cecilia Lorena VELARDE FLORES. Economic attitudes and perceptions of poverty in indigenous college students in Mexico from the intercultural approach

Table 6

Linear Regression: Financial Literacy and Satisfaction as dependent variable

\begin{tabular}{lllll}
\hline Variables & Model 1 & Model 2 & Model 3 & Model 4 \\
\hline Control Variables & & & \\
Ethnic Group & $.205^{* *}$ & $.184^{* *}$ & $.159^{* *}$ & $.147^{*}$ \\
& $(-.039)$ & $(-.037)$ & $(-.037)$ & $(-.037)$ \\
Gender & .028 & -.005 & .01 & .028 \\
& $(-.174)$ & $(-.166)$ & $(.163)$. & $(-.163)$ \\
\hline Financial optimism & & $.315^{* * *}$ & .132 & $.211^{*}$ \\
\cline { 2 - 5 } & & $(-.073)$ & $(-.094)$ & $(-.102)$ \\
\hline Estimated economy & & &. $.279^{* * *}$ & $.284^{* * *}$ \\
\hline Deterministic theory & & & $(-.092)$ & $(-.092)$ \\
\hline $\mathrm{R}^{2}$ & & & & $-.159^{*}$ \\
\hline Adjusted $\mathrm{R}^{2}$ & .34 & .141 & .184 & $(.070)$ \\
\hline $\mathrm{F}$ & .034 & $23.021^{* * *}$ & $10.787^{* * *}$ & .202 \\
\hline VIF & $4.603^{*}$ & 1.016 & 1.783 & .182 \\
\hline$* * * p<.001 ; * p<.01 ; * p<.05 ;($ standard error); VIF $=$ Variance Inflation Factor. & 1.418 \\
\hline
\end{tabular}

\section{Discussion}

In general terms, what can be obtained from these results? In summary, it can be seen that belonging to an indigenous people affects the perception of poverty. Authors such as Octavio Paz (2004), the only Mexican author to have won the Nobel Prize for Literature, argue that factors associated with poverty perceptions have affected Mexican society. This may be more evident in the original groups, which are in a situation of vulnerability (Banegas, 2015); furthermore, the findings show that this phenomenon -poverty perception- can be interpreted in the light of behavioral economics, where it is observed that economic attitudes significantly affect the perception of poverty (See Tables 4-6).

In addition, evidence shows that students find a greater acceptance to the theory of factual powers as the main cause of poverty and have greater attitudes related to financial optimism. These findings are similar to those from Merolla et al. (2011), who found that individuals who are most vulnerable to poverty rely to causal attributions. Likewise, Palomar (2003) reported that Mexicans blame poverty on external factors (political and economic) coinciding with Palomar \& Cienfuegos (2006), who also found that individuals present characteristics related to financial optimism since $44.4 \%$ of the sample indicate that one of the factors for success are the characteristics of the subject, which it is the achievement of objectives by themselves (Zabelina, 2018).

Another point of comparison is the empirical evidence of Reyes et al. (2014) who affirm that the Raramuris have the perception that the opportunities program will solve the problem of poverty that persists in their community, agreeing with the theory of the factual powers that mentions that we attribute the problems and their solution to external causes (Pinazo, 
Altayra Geraldine OZUNA BELTRÁN, Marco Alberto NUÑEZ RAMÍREZ, Imelda Lorena VÁZQUEZ JIMÉNEZ, Cecilia Lorena VELARDE FLORES. Economic attitudes and perceptions of poverty in indigenous college students in Mexico from the intercultural approach

PROBLEMS

OF EDUCATION IN THE $21^{\text {st }}$ CENTURY Vol. 78, No. 2, 2020

2010). In this regard, Torres et al. (2007) found that the Nahuatl indigenous, despite being considered poor, have characteristics of financial optimism since they are confident that their living conditions will improve. Unlike Cordera (2015), which found that the higher the level of schooling (undergraduate or postgraduate), the perception focuses on structural issues, such as the lack of support and government effectiveness.

It was shown that the economic attitude is associated with the perception of poverty, as argued by Palomar and Cienfuegos (2006), especially in the theory of factual powers. The results may serve as evidence to corroborate positions such as the one from Pinazo (2010), who maintains that the perception of poverty in underdeveloped countries is mainly due to structural aspects. Likewise, this research can be taken as empirical evidence to show the usefulness of behavioral economics and the theory of attribution (Heider, 1958), where it is mentioned that individuals by inferring about events allow to evaluate behavior and perceive social phenomena. In addition, this research is the first step to promote better programs in universities in conjunction with public policies that support poverty reduction.

However, for this to happen, a particular vision is required to enable the understanding of indigenous peoples' economic education (Brimble \& Blue, 2015). Considering that the intercultural university can play an important role in improving the living conditions of indigenous groups (Avila, 2011; Erdosova, 2013; Marquez, 2016), not only in Mexico but globally, it is important to reflect on how financial and economic education can be used to improve the reality of these peoples. Following one of the basic principles of behavioral economics: that perceptions and attitudes can positively affect economic decisions (Kahneman \& Tversky, 1979; Kahneman, 2003), intercultural education could help indigenous students to make more informed decisions. In addition, it would be desirable to promote a pedagogy that empowers students (Núñez et al., 2017) and motivates them to become involved in economic activities, such as entrepreneurship that will enable the development of their communities (Núñez et al., 2016; Peredo \& McLean, 2013). Thus, any perspective is welcome to help understand indigenous people who have historically been distinguished by backwardness and vulnerability (Schmelkes, 2013).

This research tried to go beyond a deductive and regional approach. In other words, it seeks to provide empirical evidence that allows the understanding of how behavioral economics could be used to understand the economic behavior of indigenous peoples, not only in Mexico but in other countries with indigenous populations. Considering that this issue has not been studied in depth within the indigenous context (Bajada \& Trayler, 2014; Blue et al., 2015; Wagland \&Taylor, 2015), there is the need to improve its understanding, even more so in the Latin American context, a region with a large indigenous population living in vulnerable situations. Furthermore, from the theoretical point of view, if there are approaches to indigenous entrepreneurship (e.g., Peredo, 2014), why could there not be approaches to behavioral economics applied to the indigenous context? This could only be possible through an intercultural financial education, which allows the interaction of ancestral and modern knowledge through respect and mutual support; values that can only be transmitted through an intercultural university.

\section{Conclusions}

This research studied the association between economic attitude and poverty perception in intercultural students in Mexico. Within the theoretical contributions the following may be highlighted: a) to address different dimensions of the economic attitude in individuals; b) to corroborate the relation between the study variables; c) to give continuity to the theory of attribution and the behavioral economy; d) to provide empirical evidence to the questionnaires causes of poverty in the third world and the questionnaire of economic attitudes proposed. 
Altayra Geraldine OZUNA BELTRÁN, Marco Alberto NUÑEZ RAMÍREZ, Imelda Lorena VÁZQUEZ JIMÉNEZ, Cecilia Lorena VELARDE FLORES. Economic attitudes and perceptions of poverty in indigenous college students in Mexico from the intercultural approach

The empirical contributions of this research include: (a) the characterization of economic attitudes among intercultural students; (b) the diagnosis of economic attitudes and the perception of poverty; (c) the study of interculturality through quantitative data. This research is a continuation of the attempts that researchers have made over time to evaluate the level of association of economic attitude and the perception of poverty with different variables. Different researches have postulated that the economic attitude is associated with different variables, however there was no empirical evidence that will relate it to the perception of poverty in intercultural environments; added to the above is not mentioned if the association is positive or if the economic attitude favors the perception that one has of poverty. This research was able to corroborate that the association between these variables is direct, positive and significant.

For future research, it is recommended that a study be conducted with a larger sample, trying to include a more representative population of the original groups of Mexico or of another Latin American country that also has a native population; in addition, following the behavioral economy, it would be convenient to look for other variables that can explain the perception of poverty, whether social (e.g., belief system, culture, hierarchy, well-being, gender and family structure), psychological (e.g., self-esteem, optimism and life satisfaction), and/or economic (e.g., income, employment and social mobility). Finally, from a methodological and statistical point of view, it would be convenient to use multivariate and even longitudinal studies in order to measure causality.

\section{References}

Alagoz, B. (2015). Adaptation of economy attitude scale to Turkish culture: Validity and reliability study. Academic Journals, 10(1), 17-28. https://doi.org/10.5897/ERR2014.1930

Ávila, A. (2011). Universidades interculturales y colonialidad del saber [Intercultural universities and coloniality of knowledge]. Revista de Educación y Desarrollo, 16, 19-26.

Bajada, C., \& Trayler, R. (2014). A fresh approach to indigenous business education. Education + Training, 56(7), 613-634. https://doi.org/10.1108/ET-07-2014-0079

Banegas, I. (2015). ¿Quién es pobre?, ¿Por qué es pobre? Y ¿De quién depende solucionar la pobreza?: Los mexicanos vistos por sí mismos [Who is poor? Why is poor? And who depends on solving poverty? Mexicans seen by themselves]. In R. Cordera (Eds.), Percepciones, pobreza, desigualdad. Encuesta Nacional de Pobreza [Perceptions, Poverty, Inequality. National Poverty Survey] (pp. 101 -174). UNAM.

Barraje, L. (2019). The Nobel Memorial Prize for William D. Nordhaus. The Scandinavian Journal of Economycs, 121(3), 884-924. https://doi.org/10.1111/sjoe.12383

Blue, L., Grootenboer, P., \& Brimble, M. (2015). The importance of praxis in financial literacy education: An Indigenous perspective. In M. Marshman, V. Geiger, \& A. Bennison (Eds.). Mathematics education in the margins (Proceedings of the 38th annual conference of the Mathematics Education Research Group of Australasia) (pp. 117-124). MERGA.

Brimble, M., \& Blue, L. (2015). A holistic approach to financial literacy education. ACRN Journal of Finance and Risk Perspectives, 4(3), 34-47.

Briones, C., Delrio, W., Lanusse, P., Lazzari, A., Lorenzetti, A., Szulc, A., \& Vivaldi, A. (2006). Diversidad cultural e Interculturalidad como construcciones socio-históricas [Cultural Diversity and Interculturality as socio-historical constructions] In A. Amegeiras \& E. Jure (Eds.). Diversidad Cultural e Interculturalidad [Cultural Diversity and Interculturality] (pp. 255-264). Universidad Nacional de General Sarmiento y Prometeo.

Carr, S., \& Sloan, T. (2003). Poverty and psychology. From global perspective to local practice. Springer. https://doi.org/10.1007/978-1-4615-0029-2

Cimadamore, A., Eversole, R., \& Mcneish, J. (2006). Pueblos indigenas y pobreza [Indigenous peoples and poverty]. CLACSO.

Cordera, R. (2015). Los mexicanos vistos por si mismos: Los grandes temas nacionales [Mexicans seen by themselves: The great national issues]. UNAM.
PROBLEMS

OF EDUCATION

IN THE $21^{\text {st }}$ CENTURY

Vol. 78 , No. 2, 2020

277 
Altayra Geraldine OZUNA BELTRÁN, Marco Alberto NUÑEZ RAMÍREZ, Imelda Lorena VÁZQUEZ JIMÉNEZ, Cecilia Lorena VELARDE FLORES. Economic attitudes and perceptions of poverty in indigenous college students in Mexico from the intercultural approach

PROBLEMS

OF EDUCATION IN THE $21^{\text {st }}$ CENTURY Vol. 78 , No. 2, 2020

278

Dakduk, S., González, M., \& Malavé, J. (2010). Percepción acerca de los pobres y la pobreza: Una revisión [Perceptions of the poor and the poverty: A review]. Revista Latinoamericana de Psicología, 42(3), 413-425.

Denegri, C., Sepúlveda, J., \& Godoy, B. (2011). Actitudes hacia la compra y el consumo de estudiantes de pedagogía y profesores en ejercicio en Chile [Attitudes towards the purchase and consumption of pedagogy students and practicing teachers in Chile]. Psicología desde el Caribe, 28,1-23.

Dietz, G., \& Mateos, L. (2010). Interculturalidad y educación intercultural en México [Interculturalism and intercultural education in Mexico]. Secretaria de Educación Pública.

Economic Commission for Latin America and the Caribbean [CEPAL]. (2014). Los pueblos indigenas en América Latina. Avances en el último decenio y retos pendientes para la garantía de sus derechos [Indigenous peoples in Latin America. Progress over the past decade and outstanding challenges in ensuring their rights]. Naciones Unidas.

Engelbrecht, L. (2008). The scope of financial literacy education: A poverty alleviation tool in social work? Social work/maatskaplike werk, 44(3), 252-262. https://doi.org/10.15270/44-3-239

Erdosova, Z. (2013). La Interculturalidad como alternativa educativa para la competitividad, sus logros y desafíos. Una perspectiva desde los alumnos de la Universidad Intercultural del Estado de México (UIEM) [Interculturality as an educational alternative to competitiveness, its achievements and challenges. A perspective from students at the Intercultural University of the State of Mexico (UIEM)]. Revista de Estudios en Contaduría, Administración e Informática, 1(2), 58-72.

Esguerra, G. (2016). Economía conductual, principios generales y aplicaciones [Behavioral economics, general principles and applications]. Cuadernos Hispanoamericanos de Psicología, 15(1), 67-72. https://doi.org/10.18270/chps..v15i1.1780

Feagin, J. (1972). Poverty: We still believe that God helps them who help themselves. Psychology Today, 6, 101-129.

Field, A. (2009). Discovering statistics using SPSS (3rd ed). SAGE.

Fonseca, D., de Melo, F., \& de Melo, B. C. (2019). Behavioral economics and behavioral finance: A bibliometric analysis of the scientific fields. Journal of Economic Surveys, 33(1), 3-24. https://doi. org/10.1111/joes. 12262

Giarrizo, V. (2006). La pobreza subjetiva en Argentina, construcción de indicadores para aproximarse al bienestar de la población [Subjective poverty in Argentina, construction of indicators to approximate the well-being of the population]. Universidad de Buenos Aires.

Golding, P., \& Middleton, S. (1982). Images of welfare: Press and public attitudes to poverty. Sociology of Health \& Illness, 5(2), 234-235. https://doi.org/10.1111/1467-9566.ep10491611

Hair, J.F., Black, W.C., Babin, B.J., \& Anderson, R.E. (2014). Multivariate data analysis. (7th ed.). Pearson.

Hagenaars, A., \& De Vos, K. (1988). The definition and measurement of poverty. The Journal of Human Resources, 23(2), 211-221. https://doi.org/10.2307/145776

Harper, D. (1990). Lay causal perceptions of third world poverty and the just world theory. Social Behavior and Personality: an International Journal, 18(2), 235-238. https://doi.org/10.2224/ sbp.1990.18.2.235

Heider, F. (1958). The Psychology of Interpersonal Relations. Lawrence Erlbaum Associates. https://doi. org/10.1037/10628-000

Hernández, R., Fernández, C., \& Baptista, P. (2014). Metodología de la investigación [Research methodology] (6th ed.). McGraw-Hill.

Hine, D., \& Montiel, C. (1999). Poverty in developing nations: A cross cultural attributional analysis. European Journal of Social Psychology, 29(7), 943-959. https://doi.org/10.1002/(SICI)10990992(199911)29:7<943::AID-EJSP978>3.0.CO;2-5

Ho, R. (2006). Handbook of univariate and multivariate data analysis with IBM SPSS. Taylor \& Francis Group, LLC.

Hunt, M. (2004). Race/Ethnicity and beliefs about wealth and poverty. Social Science Quarterly, 85(3), 827-853. https://doi.org/10.1111/j.0038-4941.2004.00247.x

Kahneman, D. (2003). A psychological perspective on economics. The American Economic Review, 93(2), 162-168. https://doi.org/10.1257/000282803321946985

Kahneman, D., \& Tversky, A. (1979). Prospect theory: An analysis of decision under risk. Econometrica, 47(2), 263-292. https://doi.org/10.2307/1914185 
Altayra Geraldine OZUNA BELTRÁN, Marco Alberto NUÑEZ RAMÍREZ, Imelda Lorena VÁZQUEZ JIMÉNEZ, Cecilia Lorena VELARDE FLORES. Economic attitudes and perceptions of poverty in indigenous college students in Mexico from the intercultural approach

Kaiser. T., \& Menkhoff, L. (2019). Financial education in schools: A meta-analysis of experimental studies. Economics of Education Review. Article in Press. https://doi.org/10.1016/j. econedurev.2019.101930

Kasser, T., \& Ahuvia, A. (2002). Materialistic values and well-being in business. European Journal of Social Psychology, 32, 137-146. http://dx.doi.org/10.1002/ejsp.85

Katona, G. (1975). Psychological Economics. Elsevier.

Kerlinger, F. N., \& Lee, H. B. (2002). Investigación del comportamiento [Foundations of behavioral research] (4th ed.). McGraw-Hill.

Lewis, A., \& Furnham, A. (1986). Reducing unemployment: Lay beliefs about how to reduce current unemployment. Journal of Economic Psychology, 7(1), 75-85. http://dx.doi.org/10.1016/01674870(86)90013-9

Lewis, A., Webley, P., \& Furnham, A. (1995). The new economic mind: The social psychology of economic behavior. Journal of Economic Psychology, 18(6), 713-717. https://doi.org/10.1016/ S0167-4870(97)00033-0

Loomis, J. M. (2018). Rescaling and reframing poverty: Financial coaching and the pedagogical spaces of financial inclusion in Boston, Massachusetts. Geoforum, 95, 143-152. https://doi.org/10.1016/j. geoforum.2018.06.014

Márquez, J. (2016). Evaluación del enfoque intercultural bilingüe en educación primaria indígena: estudio de caso en la región indígena Los Altos, Chiapas [Evaluation of the bilingual intercultural approach to indigenous primary education: Case study in los Altos, Chiapas]. Revista Electrónica Educare, 20(2), 1-26. https://doi.org/10.15359/ree.20-2.16

Mazabel, D., \& Diaz, S. (2011). Desmitificación y nuevos mitos sobre la pobreza: escuchando "lo que dicen los pobres" [Demystification and new myths about poverty: listening to "What the poor say]. Territorios, 24, 217-220.

Merolla, D., Hunt, M., \& Serpe, R. (2011). Concentrated disadvantage and beliefs about the causes of poverty: A multi-level analysis. Social Perspectives, 54(2), 205-227. https://doi.org/10.1525/ sop.2011.54.2.205

Ministry of Public Education [SEP]. (2018). Mapa de Universidades Interculturales [Intercultural Universities Map]. https://www.gob.mx/sep/articulos/sabias-que-existen-universidades-interculturales

Moscovici, S. (1984). Psicología social I: Influencia y cambio de actitudes. Individuos y Grupos [Social psychology I: Influence and change of attitudes. Individuals and groups]. Paidós.

Mullainathan, S., \& Thaler, R. (2000). Behavioral economics. https://www.nber.org/papers/w7948.pdf

Narayan, D. (2000). La voz de los pobres ¿Hay alguien que nos escuche? [The voice of the poor. Is there anyone to listen to us?]. Banco Mundial.

National Council for the Evaluation of Social Policy [CONEVAL]. (2018). Medición de la pobreza [Poverty Measurement]. https://coneval.org.mx/Medicion/MP/Paginas/Pobreza_2016.aspx

National Institute of Indigenous Peoples [INPI]. (2009). Informe 2009 [Report 2009] https://www.gob. $\mathrm{mx} / \mathrm{cms} /$ uploads/attachment/file/32225/cdi_informe_2009.pdf

National Institute of Indigenous Peoples [INPI]. (2018). 100 días de gobierno [100 days of goverment]. https://www.gob.mx/inpi/documentos/informes-del-instituto-nacional-de-los-pueblos-indigenas

National Institute of Statistics and Geography [INEGI]. (2015). Encuesta intercensal 2015 [Intercensal Survey 2015]. https://www.inegi.org.mx/programas/intercensal/2015/

Núñez, M., Wendlandt, T. R., \& Álvarez, M. T. (2017). Diferencias del nivel de autoestima en contextos interculturales. El caso de la Universidad Intercultural del Estado de Tabasco [Differences in the level of self-esteem in Intercultural contexts. The case of the Intercultural University of the State of Tabasco]. In B. Ramírez, Educación Superior intercultural: Trayectoria, Experiencias y Perspectivas (pp. 231-247). Colegio de Postgraduados.

Núñez, M., Wendlandt, T. R., Álvarez, M. T., \& Ortega, J. (2016). Differences in entrepreneurial skills of college students in the Mexican intercultural context. International Journal of Business and Management, 11(7), 120-129. http://dx.doi.org/10.5539/ijbm.v11n7p120

Organización de las Naciones Unidas para la Alimentación y la Agricultura [FAO]. (2015). Política de la FAO sobre los pueblos indígenas y tribales. [FAO policy on indigenous and tribal peoples]. http://www.fao.org/3/i1857s/i1857s.pdf
PROBLEMS

OF EDUCATION

IN THE $21^{\text {st }}$ CENTURY

Vol. 78 , No. 2, 2020 
Altayra Geraldine OZUNA BELTRÁN, Marco Alberto NUÑEZ RAMÍREZ, Imelda Lorena VÁZQUEZ JIMÉNEZ, Cecilia Lorena VELARDE FLORES. Economic attitudes and perceptions of poverty in indigenous college students in Mexico from the intercultural approach

PROBLEMS

OF EDUCATION IN THE $21^{\text {st }}$ CENTURY Vol. 78, No. 2, 2020

280

Organización de las Naciones Unidas para la Educación, la Ciencia y la Cultura [UNESCO]. (2015). Global Education Monitoring Report. https://www.education-inequalities.org/indicators/higher_1822\#?sort=mean\&dimension=all\&group=all\&age_group=attend_higher_1822\&countries $=$ all

Palomar, J., \& Perez, A. (2003). Un solo rostro y tres maneras de mirarlo: el significado de pobreza según el nivel socioeconómico [One face and three ways of looking at it: the meaning of poverty according to socioeconomic status]. Revista Latinoamericana de Psicología, 35(1), 27-39.

Palomar, L., \& Cienfuegos, Y. (2006). Impacto de las variables de personalidad sobre la percepción de la pobreza [The Impact of personality variables in poverty perception]. https://www.um.es/analesps/ v22/v22_2/07-22_2.pdf.

Paule-Vianez, J., Gómez-Martínez, R., \& Prado-Román, C. (2020). A bibliometric analysis of behavioural finance with mapping analysis tools. European Research on Management and Business Economics. In Press. https://doi.org/10.1016/j.iedeen.2020.01.001

Paz, O. (2004). El laberinto de la soledad, Postdata, Vuelta a El laberinto de la soledad [The labyrinth of solitude, The other Mexico, Return to the labyrinth of solitude] (3rd ed.). Fondo de cultura Económica.

Peredo, A. M., Anderson, R. B., Galbraith, C. S., Honig, B., \& Dana, L. P. (2004). Towards a theory of indigenous entrepreneurship. International Journal of Entrepreneurship and Small Business, 1(1/2), 1-20. http://www.dx.doi.org/10.2139/ssrn.1276522

Peredo, A. M., \& McLean, M. (2013). Indigenous development and the cultural captivity of entrepreneurship. Business \& Society, 52(4), 592-620. http://www.dx.doi.org/10.1177/0007650309356201

Pinazo, D. (2010). Las causas de la pobreza en el tercer mundo [The causes of poverty in the third world]. Publicacions de la Universitat Jaume I. Servei.

Quintanilla, I. (2000). Psicología Económica [Economic Psychology]. McGraw-Hill.

Reyes, J., García, M., \& Martínez, P. (2014). Percepción sobre la pobreza y el Programa Oportunidades en la Sierra Tarahumara [Perception of poverty and "Programa Oportunidades" in the Tarahumara area]. Revista de Estudios en Contaduría, Administración e Informática, 3(8), 67- 85.

Schmelkes, S. (2004). La Educación Intercultural: un campo en proceso de consolidación [Intercultural Education: A field in the process of consolidation]. Revista Mexicana de Investigación Educativa, 9 (20), 9-13.

Schmelkes, S. (2011). Adult education and indigenous peoples in Latin America. International Review of Education, 57, 89-105. https://doi.org/10.1007/s11159-011-9191-2

Schmelkes, S. (2013). Educación para un México Intercultural [Education for an Intercultural Mexico]. Sinéctica, 40, 1-12.

Shek, D. (2002). Chinese adolescent explanations of poverty: the perceived causes of poverty scale. Research on Social Work Practice, 13(5), 622-640. https://doi.org/10.1177/1049731503253376

Solis, P. (2017). Discriminación estructural y desigualdad social. Casos ilustrativos para jóvenes indigenas, mujeres y personas con discapacidad [Structural discrimination and social inequality. Illustrative cases for indigenous youth, women and people with disabilities]. CONAPRED.

Stiglitz, J. (2002). Empleo, justicia social y bienestar de la sociedad [Employment, social justice and welfare of society]. Revista Internacional del Trabajo, 121(1-2), 9-31. https://doi.org/10.1111/j.1564913X.2002.tb00364.x

The United States Agency for International Development [USAID]. (2019). Agency financial report. [Report 2019]. https://www.usaid.gov/results-and-data/progress-data/agency-financial-report

Torres, A. R., Juárez, J. P., Ramírez, B., \& Ramírez, G. (2007). Pobreza en territorios indígenas de México. El caso del municipio de Xochitlán de Vicente Suárez en la sierra nor- noriente de Puebla [Poverty in indigenous territories of Mexico. The case of the municipality of Xochitlán of Vicente Suárez in the sierra nor-east from Puebla]. Ra Ximhai, 3(3), 781-803.

Vázquez, J. J., Panadero, S., \& Rincón, P. (2007). Stressful life events in countries of differing economic development: Nicaragua, Chile, and Spain. Psychological Reports, 101, 193- 201. https://doi. org/10.2466/PR0.101.1.193-201

Wagland, S., \& Taylor, S. (2015). The conflict between financial decision making and indigenous Australian culture. Financial Planning Research Journal, 1(1), 33-54. http://handle.uws.edu. au:8081/1959.7/uws:36269 
Altayra Geraldine OZUNA BELTRÁN, Marco Alberto NUÑEZ RAMÍREZ, Imelda Lorena VÁZQUEZ JIMÉNEZ, Cecilia Lorena VELARDE FLORES. Economic attitudes and perceptions of poverty in indigenous college students in Mexico from the intercultural approach

Walsh, C. (2005). Interculturalidad, conocimientos y decolonialidad [Inter-culturality, knowledge and Decolonialism]. Signo y Pensamiento, 24(46) 39-50. http://www.redalyc.org/articulo. oa? id=86012245004

Yamani, E. (1997). The meaning of "Economics Educations" in Japanese elementary and secondary education: An historical perspective. Proceeding of the second conference of the international association for children's social and economic education. Edge hill university college/IACSEE.

Zabelina, E., Tsiring, D., \& Yu, C. (2018). Personal helplessness and self-reliance as the predictors of small business development in Russia: pilot research results. International Entrepreneurship and Management Journal, 14(2), 279 -293. https://doi.org/10.1007/s11365-018-0502-y

Received: January 15, 2020

Accepted: April 05, 2020

Cite as: Ozuna Beltran, G. A., Nuñez Ramírez, A. M., Vázquez Jiménez, L. I., \& Velarde Flores, L. C. (2020). Economic attitudes and perceptions of poverty in indigenous college students in Mexico from the intercultural approach. Problems of Education in the $21^{\text {st }}$ Century, 78(2), 263-281. https://doi.org/10.33225/pec/20.78.263

\begin{tabular}{|c|c|}
\hline $\begin{array}{l}\text { Altayra Geraldine Ozuna } \\
\text { Beltrán }\end{array}$ & $\begin{array}{l}\text { Doctor of Economics, Poverty and Social Development, Associate Professor of Economics, } \\
\text { Sonora Institute of Technology, } 5 \text { de Febrero } 818 \text { Sur, Ciudad Obregón, Sonora, México. } \\
\text { E-mail: altayra.ozuna@itson.edu.mx } \\
\text { ORCID: https://orcid.org/0000-0002-0994-0723 }\end{array}$ \\
\hline $\begin{array}{l}\text { Marco Alberto Núñez } \\
\text { Ramírez } \\
\text { (Corresponding author) }\end{array}$ & $\begin{array}{l}\text { Doctor of Management, Associate Professor of Management, Sonora Institute of } \\
\text { Technology, } 5 \text { de Febrero } 818 \text { Sur, Ciudad Obregón, Sonora, México. } \\
\text { E-mail: marco.nunez@itson.edu.mx } \\
\text { ORCID: https://orcid.org/0000-0001-5825-4482 }\end{array}$ \\
\hline $\begin{array}{l}\text { Imelda Lorena Vázquez } \\
\text { Jiménez }\end{array}$ & $\begin{array}{l}\text { Doctor of Strategic Planning, Associate Professor of Accounting, Sonora Institute of } \\
\text { Technology, } 5 \text { de Febrero } 818 \text { Sur, Ciudad Obregón, Sonora, México. } \\
\text { E-mail: ivazquez@itson.edu.mx }\end{array}$ \\
\hline $\begin{array}{l}\text { Cecilia Lorena Velarde } \\
\text { Flores }\end{array}$ & $\begin{array}{l}\text { PhD Student in Social Science, The College of Sonora, Gral. Álvaro Obregón 54, Centro, } \\
83000 \text { Hermosillo, Sonora, México. } \\
\text { E-mail: cvelarde@colson.edu.mx. } \\
\text { ORCID: https://orcid.org/0000-0002-0761-1918 }\end{array}$ \\
\hline
\end{tabular}

